\title{
The Multifaceted Nature of Legal English
}

\author{
Lilit Sahakyan \\ Yerevan Gladzor University
}

\begin{abstract}
It is beyond suspicion that legal English stands as a sublanguage of paramount international importance. The extralinguistic basis of legal English has nowadays been extended embracing conflict of overall international-social, political (both foreign and home) interests. As seen from the title of the work, the primary goal of the present article is to investigate the nature of law English. The article covers a detailed analysis of some pivotal, challenging and highly significant linguistic issues that deal with the multifaceted nature of legal English based on the comprehensive historic review of legal English. Thus, the vital importance of the subject is accounted for by the substantial and decisive role legal English plays in our social life.
\end{abstract}

Key words: legal English, law English, sublanguage, key features, precision, vagueness, multifaceted nature.

\section{Introduction}

Legal English is a language of long traditions. It is the story of Anglo-Saxon mercenaries, Latin-speaking missionaries, Scandinavian raiders, and Norman invaders, all of whom left their mark not only on England, but on the language of its law as well. Legal English developed naturally, under the influence of diverse languages and cultures, as well as the growing complexity of the legal system and the shift from predominantly oral to mainly written.

Legal English is significantly different from standard general English as it uses specialized legal English vocabulary and structure. Law English is a system and culturebound language: its special style, lexis and syntactic structure depend on the society in question and its legal reasoning. It has traditionally been the preserve of lawyers from English-speaking countries which have shared common law traditions. However, due to the spread of English as the predominant language of international business, as well as its role as a legal language within the European Union, legal English is now a global phenomenon.

\section{Historical Development}

How did legal language get to be the way that it is? To answer this questions one needs to look at the phases of the history of the language of lawyers, mainly the origins: Celts, Anglo-Saxons and Danes, as well as the impact of the adoption of Christianity, Christian missionaries and Latin, the Norman Conquest, the introduction of French, French-speaking Normans and Anglo-French, as well Law French, the demise of Latin and Law French on the law and legal English. ${ }^{1}$ And how does the language of the law differ from ordinary speech and writing? The hot issue to be considered in this article is the great difference 
between legal English and ordinary English. Modern legal English is based on Standard English. Nevertheless, law English differs from standard English in a number of ways. It contains a number of unusual key features largely relating to terminology, linguistic structure, linguistic conventions, and punctuation, etc., all of them having their roots in the history of the development of English as a legal language (Butt, Castle 2006; Elwell, Smith 1996; Haigh 2006, 2009; Klinck 1992; Mellinkoff 1982; Murray, Muldoon 2004; Putman 2003; Tiersma 2000). One thing to be emphasised is that the mastery of ordinary English does not imply the mastery of legal English. Those differences are based on certain categories, and their basic elements, standing as specific markers of legal English. The points given below portray the multifaceted nature of legal English based on its basic elements, mainly lexical, grammatical and syntactic specific features and significant key features. Those key features are studied with the aim of providing a comprehensive description of some pivotal and challenging issues that expose the multifaceted nature of legal English.

\section{Key Features of Legal English}

Key Feature N1. Terms of art. One of the ways in which the language of the law is claimed to promote clear and concise communication is mainly through a specific legal vocabulary. Legal English, in common with many other professional languages variations, employs a great deal of specialized words and phrases unique to law that have relatively exact meanings ${ }^{2}$, are used by legal professions, promote brevity of expression, and fulfill an important communicative function. These distinctive units of vocabulary terms of art - have technical meanings, and such technical terms as waiver, restraint of trade, restrictive covenant, promissory estoppel, as well, tort, fee simple, and novation, etc., are not generally familiar to the layman.

Key Feature N2. Obscure words or phrases. There is a tendency in legal writing to use unnecessary obscure words or phrases rather than their ordinary equivalents, perhaps out of a feeling that the obscure words are somehow more impressive. Here are the most commonly used obscure words or phrases implemented in legal English parallel to their single word equivalent: annex - attach, append - attach, cease - stop, conceal - hide, demise - death, desist - stop, leave off, detain - hold, delay, determine / terminate - 1. end, 2. decide, donate - give, effectuate - carry out, endeavour - try, evince - show, expedite - hasten, expend - spend, expiration / expiry - end, extend - give, extinguish - end, forthwith - immediately / soon, forward - send, furnish give / provide, implement - carry out / fulfill, inaugurate - begin, indicate - state / show / say, initiate - begin, necessitate - require, occasion (v.) - cause, peruse read, possess - have, present - give, prior - earlier, prior to - before, proceed go (ahead), quantum - amount, retain - keep, suborn - bribe (e.g., a juror or witness), subsequent to - after, subsequently - then / after / later, utilise - use, until such time - until, etc..

Key Feature N3. Quotidian words. Ordinary words both in general English and legal English exhibit certain systematic lexical relationships, e.g., words can be related 
as homonyms, or via polysemy. But this can cause communication problems when legal terms have both an ordinary meaning and a divergent legal meaning. For example, there are quotidian words used in apparently peculiar contexts in legal English as compared to their ordinary meanings in general English, e.g., distress - 1) n. the self-help taking of another's possessions in order to force payment of a claim, which is generally illegal without a court order, 2) adj. at lowest price due to negative circumstances, entertain v. - to consider (e.g., a lawsuit), execute - to sign to effect, find v. - to resolve, to make a legal decision in a law court, furnish $\mathrm{v}$. - to give, provide, to present (associated concepts may include furnish proof, labor furnished, material furnished, work furnished), hold to resolve, to decide legally, to conclude, etc.. These words are particularly problematic because laymen are very likely to misinterpret them, and even courts are sometimes unsure whether the ordinary or technical meaning was intended.

Key Feature N4. Wordiness and redundancy. Lawyers are very prone to wordiness and redundancy, using wordy and redundant phraseology. For example, lawyers tend to use ponderous phrases (such as subsequent to) where a single word would suffice (after). Other examples of frequently used ponderous phrase parallel to their single word equivalent include be a significant factor in - affect / influence, be inclined to the view that - think that, be in a position to - can / may, by dint of - because, during the time that - during, give rise to / have the effect of - cause, have a detrimental effect upon harm, have an affect upon / impact upon - affect, in spite of the fact / notwithstanding the fact that - despite / although, having regard to - concerning, in the event that if, in view of - because, it is arguable that - perhaps, etc..

On the one hand, lawyers avoid synonyms or elegant variation as using a different word is assumed to invoke a different meaning. On the other hand, lawyers have a great love for long lists of synonyms, especially in legal doublets, triplets and quadruplets (dublicate / triplicate / quadruplicate words / alliteration and conjoined phrases). In Anglo-Saxon legal culture, the complexity of Anglo-Saxon law led to more linguistically complicated legal language, for instance, there was a curious historical tendency in stringing together two or three words to convey what was usually a single legal concept. The practice of the usage of alliteration and conjoined phrases dating back to AngloSaxon times has survived to the present. These conjoined phrases consisting of words like and and or, are extremely common in legal English. Examples of this include such legal doublets like fit and proper, fraud and deceit, null and void, perform and discharge, sole all and sundry, successors and assigns, and such legal triplets as give, devise and bequeath, the rest, residue and remainder, dispute, controversy or claim, promise, agree and covenant, possession, custody and control, and also legal quadruplets as in lieu, in place, instead and in substitution of, etc.. Such constructions need to be treated with caution, since sometimes the words used mean, for practical purposes, exactly the same thing (as in case of null and void); and sometimes they do not quite do so (as in case of dispute, controversy or claim, possession, custody and control). One reason for such lists of words is to be as comprehensive as possible. They also can add emphasis. But the lists of synonyms can thus create interpretative problems leading to 
ambiguity. Consequently, careful communication requires that lawyers use such conjoined phrases with care.

Key Feature N5. Archaic language vs. novel terminology. The language of the law is neither utterly conservative nor exceptionally innovative, and as a mere outcome, legal English is an odd mixture of archaic alongside very innovative features. Legal writing employs many archaic vocabulary / legal archaisms that were formerly quotidian language, but today exist only in law, dating from the 1500s. Use of pronominal adverbs or here-, there- and where- words like hereof, thereof, and whereof (and other derivatives, including --above, -after, at, -before, -by, -in, -inafter, -of, -on, -to, -tofore, -under, -upon, -with, etc.) are not often used in ordinary English. Nevertheless, they are used in legal English primarily as a way of avoiding the repetition of names of things in the document or the document itself. For example, the parties hereto instead of the parties to this contract, or the provisions contained hereinafter instead of the provisions referred to later on in this contract. However, archaic pronominal adverbs used in Legal English persist in modern legal usage largely as a consequence of legal tradition rather than usefulness.

Moreover, legal vocabulary is full of antiquated features including a. archaic morphology (further affiant sayeth not), b. the legal use of same, said, aforesaid, such and to wit, or said and such as adjectives, and c. use of the subjunctive, especially in the passive (e.g., be it known). Although these legal archaisms and antiquated features often had a legitimate function in the past, and often there were reasons, conflicting motivations and goals for using antiquated vocabulary (such as the reluctance of religious language adherents to change or even to translate sacred or authoritative texts for not affecting their meaning, or to justify lawyers ' high fees), the claim that these antique features should be preserved nowadays because they are somehow more precise than ordinary language is simply not defensible.

Even though some legal language is quite archaic, and many other old legal terms have died off as the concepts to which they refer became obsolescent, in fact, when dealing with new legal concepts for which there is no existing word, lawyers do not hesitate to create novel terminology. Consequently, some areas of the legal lexicon are very innovative, as in terms like zoning, palimony, e-contract, e-signature, e-postmark, clickwrap agreement, shrink-wrap licences, clickwrap licences, browsewrap licences, etc.. Such terms give the law the ability to deal with novel circumstances and legal developments.

Further, another example of linguistic creativity in legal language is the frequent formation of new words ending in -ee, which contrast to those ending in -or/-er. Legal English contains a large number of names and titles, such as employer and employee, mortgagee and mortgagor, assignee and assignor, or lessor and lessee, in which the reciprocal and opposite nature of the relationship is indicated by the use of alternative endings. This practice derives from Latin. Although these pairs are confusing for the lay public, they can enhance communication within the profession by filling lexical gaps that exist in ordinary language. 
Key Feature N6. Latinisms and French survivals. Law English is abundant with loan words and phrases from other languages. Some Anglo-Saxon words or legal terms have survived to today, including writ, ordeal, witness, deem, oath and moot. Also, a large amount of loan technical vocabulary, including many of the most basic words in our legal system, includes terms and terminological combinations derived from French (attorney-at-law, autrefois acquit, bailiff, cestui que trust, culprit, cyprès doctrine, defendant, escheat, estoppel, feme covert, feme sole, force majeure, laches, mortgage, oyez, plaintiff, puisne, replevin, torts, trove, voir dire, etc.) and Latin (ad hoc, bona fida, certiorari, de facto donatio, ex parte, habeas corpus, inter alia, inter vivos, mens rea, mala prohibita, mortis causa, prima facie, res judicata, sub judice, sub silentio, sua sponte, ultra vires, etc.). As a rule, in legal instruments they are not italicised as English legal language, as would be foreign / loan words in mainstream English writing. To make it worse, in some cases, parallelly are used both the loan and the native terms for the same legal phenomenon, such as, Eng. previously acquitted $\rightarrow$ Fr. autrefois acquit, Eng. previously convicted $\rightarrow$ Fr. autrefois convict, Eng. estoppel by conduct $\rightarrow$ Fr. estoppel in pais, excess of jurisdiction $\rightarrow$ Lat. ultra vires, Eng. legally permissible $\rightarrow$ Lat. legitimate, Eng. guilty knowledge $\rightarrow$ Lat. mens rea, Eng. unlawful act or behaviour / misdeed / misdemeanor $\rightarrow$ Lat. actus reus, Eng. among others $\rightarrow$ Lat. inter alia, Eng. letter citatory $/$ citation $\rightarrow \quad$ Lat. subpoena, Eng. witness summons / citation $\rightarrow$ Lat. subpoena ad testificandum, Eng. action / suit $\rightarrow$ Lat. lis, Eng. autopsy $\rightarrow$ Lat. post mortem, Eng. immunity $\rightarrow$ Lat. habeas corpus, Eng. in court $\rightarrow$ Lat. ad litem, Eng. survivorship $\rightarrow$ Lat. jus accresendi, Eng. so-called $\rightarrow$ Lat. soi disant, etc..

As well, legal maxims, even today, are often in Latin, which gives them a sense of heightened dignity and authority. Also, names of writs (mandamus, certiorari) and terminology for case names (versus, ex rel., etc.) are still in Latin. Furthermore, some of the other characteristics of Law French that have left traces in today's legal language include addition of initial $\boldsymbol{e}$ to words like squire, creating esquire, and simplification of the French verb system, so that all verbs eventually ended in -er, as in demurrer or waiver. As an outcome, in legal English, it is more difficult to achieve clarity in practice than it is in ordinary English, because much of the terminology used comes from French and Latin.

Key Feature N7. Legal slang. Despite claims on lawyers' very formal, even pompous speech habits, frequent use of legal slang, enhancing group cohesion and ensuring shortness, is evident, as well.. Examples include rogs for interrogatories; stir, porridge for prison or imprisonment; mug shot for photo of a criminal; tro for temporary restraining order; slapp suit for strategic lawsuit against public participation; horse shedding for subornation of perjury, and grant cert for grant a writ of certiorari, etc.

Key Feature N8. Avoiding pronouns. One means of gaining precision is to repeat nouns (e.g., player), rather than using a pronoun (e.g., he) after a person or thing is introduced. Pronouns can sometimes have ambiguous reference, so this technique can indeed enhance precision. Lawyers, however, avoid pronouns almost routinely, even where no 
ambiguity is possible. Avoiding pronouns does have an unintended benefit, mainly it reduces the use of sexist language.

Key Feature N9. Unusual word order. Lawyers often adopt an unusual and distinctly strange word order. There is no single clear reason explaining this phenomenon, although the influence of French grammatical structures is certainly a contributing factor. Here are some typical examples in case of which adjectives normally follow the noun that they modify as it is in French. Such as, accounts payable, attorney general, court martial, fee simple, letters testamentary, malice aforethought, solicitor general, title absolute, treasure trove, as well before as after any judgment, the title above mentioned, etc.. Such specificities cause little trouble for lawyers, for whom inverting word order becomes second nature. But they trouble the non-lawyer, unfamiliar with such linguistic eccentricities.

Key Feature N10. Unusual and complicated syntax. Syntax in legal language is quite a bit more unusual and complicated than in other styles. To illustrate this point let us note that English lawyers have the tendency to make use of such obvious markers as:

a) unusual sentence structures (e.g., separating the subject from the verb, or splitting the verb complex),

b) lengthy and complex sentences with intricate patterns of coordination and subordination, abundant with

c) multiple negations / negative structures (aimed at softening the impact of what is being said by using not un-/ im- / il- / in, etc., such as: not inconsiderable, not unjustifiable, not negligible, etc.),

d) syntactic devices, strategically creating objectivity and authoritativeness, such as the frequent use of

1. impersonal constructions (e.g., the avoidance of first and second person pronouns and using the third person, or the tendency of judges to refer to themselves as the court rather than $I$ ), and

2. passive constructions (strategically to omit reference to the actor, thus de-emphasizing or obscuring the identity of the actor, and being deliberately imprecise), as well

f) nominalizations (i.e., nouns derived from verbs, e.g., cancel- cancellation, legalize-legalization, mislabel-mislabeling), and the last but not the least,

g) with an eye-catching lack of punctuation (e.g., some statutes or linguistic principle that can easily be broken down into more digestible pieces with no loss in content, are formulated as one sentence without any punctuation except for a final full stop).

Such commonly stressed syntactic characteristics of legal style reduce comprehension, make the meaning less clear and definite, as well inappropriate or ambiguous, thus impairing precise communication.

\section{Conclusion}

As an outcome of our study, we got assured in the multifaceted nature of legal English highlighting its flexibility, precision and vagueness, gained as a result of making use of 
terms of art, wordiness and redundancy, conjoined phrases and lists of words, quotidian words, archaic or rarely used words and expressions, Latinisms and French survivals, unusual word order, intricate and unusual sentence structures, long and complex sentences with specific syntactic devices, etc.. Indeed, each of the above listed factors, accompanied with pertinent explanatory notes and relevant interpretations on selected examples, came to mirror the multifaceted nature of legal English, as a language having its own specialized grammar, lexical, syntactic and semantic specificities that are not acceptable in the standard language. Nevertheless, it would be inaccurate to suggest that legal English is nothing more than formal written language with some specific features. Better to conclude by stating that legal English is an English sublanguage of long traditions, standing distinctively somewhere between a separate language and ordinary English, with either highly precise or maddeningly vague collection of linguistic habits and specifically complex multifaceted nature, developed over many centuries.

Notes:

1. For further detailed information on the historical development of law English See Sahakyan, L. S. (2014) Insights into Legal English (teaching and methodology). Yerevan, pp. 85-89; Sahakyan, L. S. (2011) Legal English Terminology as an Outcome of Historical Developments // "Gladzor-20": Hodvatsneri hobelyanakan zhoghovatsu./ Ed. by Zh. Jhangiryan, A. Sargsyan, et. all. Yerevan Gladzor University, Yerevan: Noyan Tapan, pp. 674-687; Baker, J. H. (1990) An Introduction to English Legal History (3rd edition). London: Butterworths; Baker, J. H. (1990) Manual of Law French (2nd edition). Aldershot, Eng.: Scolar Press; Hiltunen, R. (1990) Chapters on Legal English: Aspects Past and Present of the Language of the Law. Helsinki: Suomalainen Tiedeakatemia; Williams, Ch. (2007) Tradition and change in legal English: Verbal constructions in prescriptive texts. Germany: Peter lang..

2. Such terms are less exact in law than in other sciences because legal terms typically refer to concepts that change over time, or are slightly different in divergent jurisdictions, and, of course, they may be modified by judicial decisions.

\section{References:}

1. Baker, J.H. (1990) An Introduction to English Legal History (3rd edition). London: Butterworths.

2. Baker, J.H. (1990) Manual of Law French (2nd edition). Aldershot, Eng.: Scolar Press.

3. Butt, P.; Castle, R. (2006) Modern Legal Drafting: A Guide to Using Clearer Language. Cambridge: CUP.

4. Elwell, C.C.; Smith, R.B. (1996) Practical Legal Writing for Legal Assistants. USA. 
5. (2009) Guide to Court Reform and the Role of Court Personnel: A Guide for USAID Democracy and Governance Workers USAID, Washington, D.C.

6. Haigh, R. (2006) Oxford Handbook of Legal Correspondence. Oxford: OUP.

7. Haigh, R. (2009) Legal English (2nd edition). Routledge-Cavendish, Taylor \& Francis Gr..

8. Hiltunen, R. (1990) Chapters on Legal English: Aspects Past and Present of the Language of the Law. Helsinki: Suomalainen Tiedeakatemia.

9. Klinck, D.R. (1992) The Word of the Law: Approaches to Legal Discourse. Ottawa: Carlton University Press.

10. Mellinkoff, D. (1982) Legal Writing: Sense and Nonsense. St. Paul: West Publ..

11. Murray, G.E.; Muldoon, G. (2004) Criminal Law Language of New York. Florida: Gould Publ.

12. Putman, W.H. (2003) Legal Analysis and Writing (3rd edition). Delman Cengage Learning.

13. Sahakyan, L. (2014) Insights into Legal English (teaching and methodology). Yerevan: "AGH" Press.

14. Sahakyan, L.S. (2011) Legal English Terminology as an Outcome of Historical Developments // "Gladzor-20": Hodvatsneri hobelyanakan zhoghovatsu. / Ed. by Zh. Jhangiryan, A. Sargsyan, et. all. Yerevan Gladzor University, Yerevan: Noyan Tapan.

15. Tiersma, P. (2000) Legal Language. Chicago: Univ. of Chicago Press.

16. Williams, Ch. (2007) Tradition and Change in Legal English: Verbal Constructions in Prescriptive Texts. Germany: Peter lang.

17. Garner, B. (2003) A Dictionary of Modern legal usage (2nd edition). New York: OUP.

18. Gifis, S.H. (1993) Dictionary of Legal Terms (2nd edition). Barron's Publ..

19. Hill, G.N.; Hill, K. (1997) Real Life Dictionary of the Law: Taking the Mystery out of Legal Language. General Publishing Group.

20. Riley, D. (1996) Check Your Vocabulary for Law: Dictionary of Law (2nd edition). Peter Collin Publ..

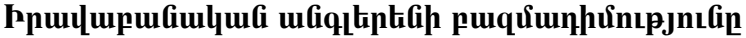

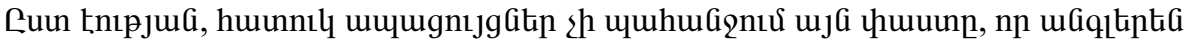

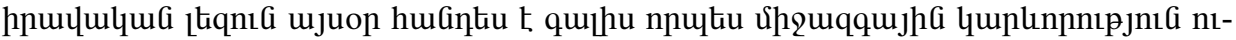

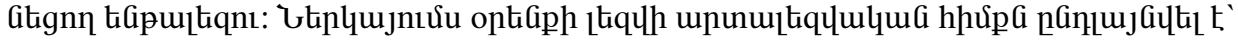

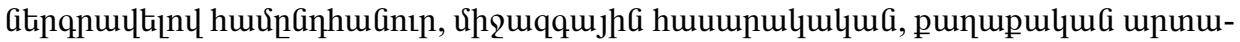

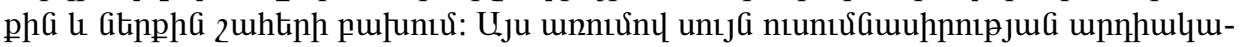

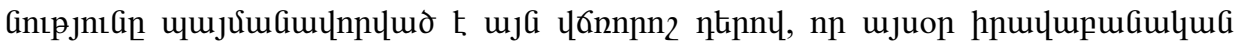

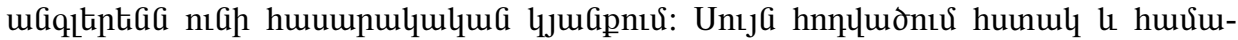

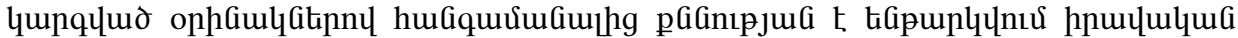

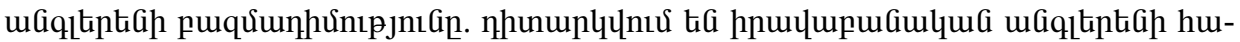

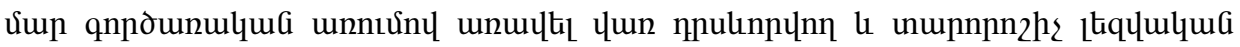

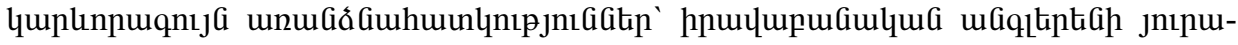




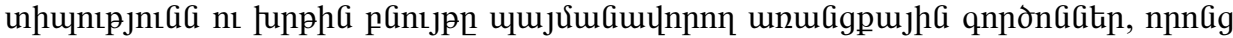

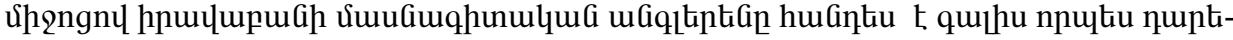

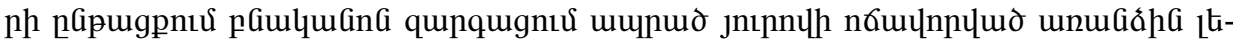

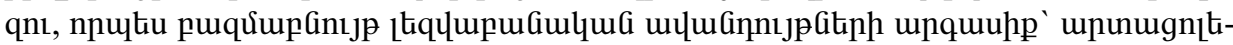

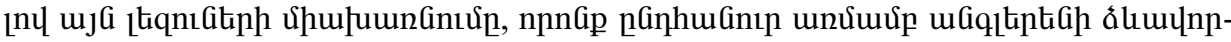

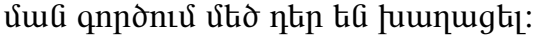

\section{Многогранность юридического английского}

В настоящее время не требуются особые факты о том, что юридический английский выступает в качестве подъязыком первостепенного международного значения. Экстралингвистическая основа юридического английского расширилась, включая в себя столкновения всеобих, международно общественных, политических внешних и внутренних интересов. Актуальность исследования связана с той значимой ролью, которую играет юридический английский в общественной жизни. Статья посвящена тщательному анализу многогранной сущности юридического английского. С помощью конкретных примеров рассматриваются наиболее яркие ключевые языковые особенности юридического английского с функциональной точки зрения, что и позволяет выявить важнейшие факторы становления профессионального языка закона в результате хронологического развития английского языка в целом. Учитываются также различные языковые традиции, сыгравшие ключевую роль в формировании многогранной сущности юридического английского. 